DOI Number: 10.30520/tjsosci.681347

\title{
SOME CONSIDERATIONS ON THE POLITICAL ACTIVITIES OF SARA HATUN, THE FIRST DIPLOMAT IN TURKISH-ISLAMIC HISTORY
}

\author{
TÜRK ISLAM TARIHININ ILK DIPLOMAT HANIMI SARA HATUN'UN SIYASI \\ FAALIYETLERİ ÜZERINE BAZI MÜLAHAZALAR
}

Vesile SHEMSHEK ${ }^{1}$

\begin{abstract}
During the history of turkic politics, it is observed turkic women close interaction in external and internal issues of the government and their huge impact on state policy. Primarily, mothers, wifes, sisters of rulers had more chance in participation of the matters regarding state politics and diplomatic relations. Their official political satatus is obvious as a matter of fact that these women's names were printed on edicts, records, and inscriptions. One of the leading woman who has crucial impact on state affairs is Sara Khatun. She is smart, intelligent turkic muslim woman with deep strategy in diplomacy and politics. Ottoman sources name her as Govharshah Khatun and describe her as a first female diplomat with turkic muslim origin. In this study, we try to reveal the political and cultural activities of Sara Khatun, who has distinguished role in turkic political history with her important contributions to the history of diplomacy, as well as to benefit from counciousness of these historical contributions.
\end{abstract}

Keywords: Sara Khatun, political activities, history of Turks, Ak Koyunlu empire

\section{ÖZET}

Türk siyaset tarihi sürecinde, devletin iç ve dış ilişkilerinde çeşitli vazifelerle ile üstlenen hanımların, önemli misyonlar icra ettikleri görülmektedir. Nitekim, Türk tarihinin çeşitli dönemlerinde, devlet yönetiminde bulunan hükümdar eşleri ve anneleri olan hatunlarının devlet siyasetine ve diplomatik ilişkilere yön verdikleri de bilinmektedir. Bu hanımlar, devletin iç ve dış siyasetinde etkinliğini koyarken yönetimde söz sahibi olmuş, ferman, vakıf kayıtları ve kitabelere kendi adlarını basarak diplomasinin önemli bir unsuru olmuştur. Tarih sahnesinde devlet işlerinde öne çıkan diğer hanımlardan, Ak koyunlular 'da ise Sara hatun iradeleri, akıllı ve zeki siyasî hamleleri, himayeci tavırları ile siyasî ve idarî hayattaki etkinliklerini sürdürmüşlerdir. Türk devletçilik tarihine ilk bayan diplomat olarak geçen Sara Hatun, bir Türk Müslüman kadınıdır. Osmanlı kaynaklarında yazıldığı üzere, onun gerçek adı Gövherşah Hatun'dur. ilk bayan diplomat olarak bilinen ise, Türk Müslüman Sara Hatun'dur. Dolayısıyla birbirine benzer gelenekleri sürdüren iki Türkmen devlette bu hatunun diplomasi ve devlet politikasındaki etkin rollerinin incelenmesinde fayda görülmektedir. $\mathrm{Bu}$ çalı̧̧mamızda, Türk siyaset tarihi sürecinde seçkin diplomasi terakkilerine önemli katkılarda bulunan Sara Hatun'un devletçilik politikasında uyguladığı siyasi ve kültürel faaliyetlerini ortaya çıkarmak ve tarih bilincine fayda sağlamaktır.

Anahtar Kelimeler: Sara Hatun, siyasi aktiviteler, Türk tarihi, Ak koyunlu devleti

\footnotetext{
'ORCID: 0000-0002-9800-4557 Dr. Faculty member, Kastamonu University, Faculty of Theology, Department
} of Islamic history, vsemsek@gmail.com 


\section{INTRODUCTION}

Throughout the history, Turkic women have been distinguished by wisdom, prudence, loyalty to their homeland and family, and have managed to overcome all the trials of life and hardships of time with dignity and honour, along with guiding men to the right path. One of the greatest example is Tomiris, a brave woman who battled against Cyrus, the Achaemenid ruler. Tomiris Khatun was the first ruling lady in the history of Turkic politics to rule the Massagetae tribe in the north of the Aras river in Azerbaijan for sixty years, deserving the name of the longest female ruler in the history of politics. Other examples in the history are women such as Berde ruler Nushaba, Mumine Khatun, Javad Khan's life partner Beyim Khatun, Khurshidbanu Natavan, Mahpeyker Sultan - Haseki Sultan to Ahmed I Kosem, etc.

During the 14th-15th century, many rulers' spouses or mothers put their effectiveness in the domestic and foreign politics of the state, as we can see their names were printed, as a people who had a say in administrative matters, in foundation records and inscriptions as an important element of diplomacy.

\section{ESTABLISHMENT PROCESS OF AK KOYUNLU STATE}

Towards the end of the 15th century, Ak Koyunlu people started an effort to establish a state using opportunity of weakness of Kara Koyunlu due to internal strifes. While there was a big decline in economic situation at the state of Kara Koyunlu, as a result of uprising and internal disturbance, Ak Koyunlu family started have more power and authority over the territory of Diyarbakir, Mardin and the surrounding regions. As Ak Koyunlu's power start to increase, they demand political support from the Greek emperor Trapezand and gave high importance to have good relations with the Teymuris. On the other hand, Shahruh Shah used the Ak Koyunlu to keep the Karakoyunlu under his rule. As a matter of fact, while the Kara Koyunlu were fighting against the Teymuris to defend Tabriz, the Ak Koyunlu ruler Kara Osman Yulug (1394-1434) captured Erzinjan and Sivas and it was hard defeat for Kara Koyunlu . Especially Uzun Hasan, who was particularly prominent with his political and military struggles with the Kara Koyunlus, defeated the Kara Koyunlu in 1460 and captured a large part of the territory of modern Armenia and Georgia. Thus, after long struggles, the Ak Koyunlu state was established in Azerbaijan. On the other hand, Jahan Shah also captured Khorasan territory expanding territories under his rule to Iran and signed a peace treaty with the Teymuris. In the fierce battle between Uzun Hasan and Kara Koyunlu in Mush in 1467, Kara Koyunlu suffered heavy defeat and since then was erased from the historical scene . Thus, the process of political domination of Ak Koyunlu empire began in Azerbaijan. Although the heirs of Jahan Shah tried for the 'resurrection' of the Kara Koyunlu empire again, their efforts ended useless. However, they had alliance with Abu Said, the ruler of Khorasan, to prevent possible danger from the Ak Koyunlu. As a matter of fact, Emir Said was also uncomfortable with the strength and political dominance of Ak koyunlu in the region. 


Year:4, Volume:4, Number:7 / Yol:4, Cilt:4, Sayı:7 / 2020

\section{SARA KHATUN'S POLITICAL ACTIVITIES}

Sara Khatun is mentioned as Uzun Hasan's mother in resources, however not much information is available about her family roots. It is mentioned that her grandfather's name was Pir Ali, but not much known about his identity. On the other hand, as per information by Dukas, Sara Khatun is considered as Komnenian princess due to the fact that Kara Yulug Osman Bey IV married to Alexios ' daughter. (Baykal, 1964: 71), Sara Khatun, daughter of Pir Ali Bey, one of the Sons of Ak Koyunlu Gutlug Bey and niece of Kara Yulug Bey, founder of Ak Koyunlu empire, and she married to Ali Bey, the eldest son of Osman Bey. From this marriage she had seven sons and one daughter. Her sons are Uzun Hasan, Jahangir, Husain, Jahan Shah, Iskender, Ibrahim, Uveys. (Sumer, 1991: 209-211). Her daughter is Khadija Begum, who married to the Safavid Sheikh Juneit. (Sumer, 1989: 272) While there is no record of Sara Hatun's birth year, the date of her death is not certain either, but in 1465 Sara Khatun's name is mentioned in various forms in various sources such as Sare Khatun, Sarah Khatun, Sara Hatun or Saray Khatun(Hanım). However, there is some information that name of Saray was wide spread among Turkmen women and therefore, in some sources Sarah Hatun's original name is considered as Saray Hatun (Sumer, 1998: 690). Though we don't have so much information about her identity, Sara Khatun assumed important duties in foreign and domestic policy of Ak Koyunlu empire in 15th century and became one of the most important personalities of the period with her cautious politics. Like Khatun Jan Begum from Kara Koyunlu, Sarah Khatun sometimes demonstrated her influence in resolving disputes between her sons, and sometimes she met and negotiated with the rulers of neighbor states. As a matter of fact, in early 1451, she came to Cairo and brought Jahangir's son's letter where expressed thankness and devotion to his father (Birdi, 1930: 79-130; Virtue, 1990: 120)

Sara Khatun made diplomatic contact with the Mamluk sultan for the second time. In fact, he kept Harput under his administration for a while, then Uzun Hasan sent the key to Harput Castle to the Mamluk sultan Hosh Kademi with the delegation who lead his mother Sara Khatun. Sara Khatun was welcomed with great hospitality and high respect by the Mamluk Sultan. She received valuable gifts and returned back to her palace after staying in Cairo for a while. (Iyas, 1982: 437,Birdi, 1930: 510). We can see that Sara Khatun tries to resolve the political events in Kara Koyunlu and Ak Koyunlu by acting as an ambassador. In one of the ongoing struggles between Ak Koyunlu and Kara Koyunlu, Rustem-i Tarhan from Kara Koyunlu sent a blind messenger Pir Mezid to Ak Koyunlu Jahangir to remind about kinship between them and requested him send his mother to Jahan Shah in order to improve the relations between Ak Koyunlu and Kara Koyunlu (Najafli, 2006: 43). Jahangir took into consideration offer from Rustam-i Tarhan and without notifying his brother Uzun Hasan sent his mother and his son to Jahan Shah palace to initiate negotiations to end hostile relations and make a deal, while Uzun Hasan was in northwest part of Diyarbakir in order to resist against Kara Koyunlu (Lighter 2005: 93). When Sara Khatun came to Jahan Shah's Palace, she was welcomed very well with respect and honour. Afterwards Jahan Shah said to Sara Khatun: " One of the two brothers, either Jahangir Mirza or Hasan Bey, better come here and make peace with truth and sincerity", and she replied: "Their arrival is almost imposible 
and if I promise that they will come to your palace and if this doesnt happen, I will be a liar on this issue". Jahan Shah's harem said: "If they do not come, it will be your sons' fault ", and Sara Khatun replied: "Husain, the Emir of believers, was martyred at the hands of the oppressors in the desert of Karbala. There is possibility that my sons will be martyred at the hands of the oppressors. We as a human have no power to run from whatever granted for us. Because God's will cannot be prevented: He does what he wants and judges as He wants" . Then she informed Uzun Hasan Bey and Jahangir Mirza that if they come, victory will be theirs (Rumlu, 2006: 294).

As a diplomat and stateswoman, Sara Khatun was well known not only in the East, but also in Europe for her political activities. Taking into account her authority in the Ak Koyunlu Palace, the senator of the Republic of Venice, within diplomatic visits of his diplomats to Azerbaijan, he instructed them to respect status of Sara Khatun and to represent on behalf of state various valuable gifts as a sign of consideration of her high authority. Her experience in diplomacy were highly appreciated. Sara Khatun is mentioned in almost all diplomatic documents sent from Venice to Azerbaijan (Ismail, 1993: 137-138).

Sara Khatun was given permission to return from Kara Koyunlu ruler Jahan Shah's Palace without offering donations, gifts. 45. Sarah Khatun's son Jahangir refused the request of Jahan Shah, to come to Kara Kkoyunlu Palace as a hostage. Jahan Shah, who was increasingly interested in the events in the East and in order to expand his authority over Timurid lands, decided to have better relations with Ak Koyunlu and reduce potential threat. With the efforts of Sara Khatun, Jahan Shah signed the Treaty of Amit in 1452 with her son Jahangir (Woods, 1993: 142). According to this agreement, Jahangir will recognize Kara Koyunlu sovereignty in Diyarbakir, marry his daughter to Muhammad, son of Jahan Shah, and send his son Muradi as a hostage to Jahan Shah's Palace. After the defeats in the Ak koyunlu-Kara Koyunlu struggle under the command of the Emir Rüstem Tarhan, Jahan Shah realised that no Kara Koyunlu ruler had ever been able to do so by mere arms as Sara Khatun did through diplomacy. As a result, Jahangir got Mardin while gave up his absolute sovereignty and it lead many Turkmen tribes turn away from him (Woods, 1993: 143). Sara Khatun made big efforts to improve internal politics and was mediator between her sons Uzun Hasan and Jahangir while disputes appeared regarding Ak Koyunlu and Kara Koyunlu strugle. After failure of cooparation plan with Kara Koyunlu Jahangir sent his mother Sara Khatun from Mardin as an envoy to clarify the death of Osman the Kurd, while Uzun Hasan moved from Rasul Ayn to Shina. Actually his real purpose was to find possible solutions for peace (Virtue, 1990: 127).

Sarah Khatun visited Uzun Hasan to settle a dispute between her sons. Uzun Hasan told his mother, " Ak Koyunlu and Karakoyunlu have been defecting to each other. There's always this kind of coming and going between the two sides. However higher rank people from our dynasty have never sought asylum and protection in Kara Koyunlu side. The union between my brother Jahangir Mirza and Jahan Shah is not acceptable". He complained this fact to his mother and expressed his discomfort about the cooperation between Kara Koyunlu and Ak 
Koyunlu (Tihrani, 2001: 153). Then, he told his mother Sara Khatun his demands reagarding his brother Jahangir as following: the last one should send his son to Uzun Hasan's palace as a hostage; Jahangir have to deny from the reign of Ak Koyunlu and Mardin will be under surveilance of Ak Koyunlu. Uzun Hasan's demands were intended to achieve unity and stabilty at the state, as well as remove any potential opponents to the throne and protect his dominance as a ruler (Erduş, 2003: 57). However, when Jahangir refused these demands, there was battle between them and Pir Haji and Pir Mihma from Jahangir side and Mohammadi Halil Inak and Isa Bey from Uzun Hasan's army were killed. However, Uzun Hasan's army chased Jahangir's troops down to Aqaba. After being defeated Jahangir was in desperate situation and that's why he sent his mother Sara Khatun to Uzun Hasan to make a deal. Uzun Hasan insisted on his previous demand to have Jahangir's son as a hostage in his palace. Meanwhile, Uzun Hasan defeated Kara Koyunlu and its allies and encircles Mardin again. The people of Mardin, who were in a difficult situation, came to Jahangir and told him their demands by saying, "Listen to your brother and give him your son as a hostage, if Uzun Hasan continues to fight against us, we will not be able to resist him any longer." After that, when there was no food left in Mardin, Sara Khatun persisted in her attempts to make peace between her sons. Upon the request of Mardin people and the efforts of Sara Hatun, Jahangir sent his son Ali Khan to Uzun Hasan's Palace as a hostage and an agreement was made between them. As a result of the agreement between Uzun Hasan and Jahangir, Diyarbakir was left to Uzun Hasan and Mardin to Jahangir. Thus, the conflict between two Ak Koyunlu brothers Jahangir Mirza and Uzun Hasan ended for a while with the attempts of Sara Khatun.

Sara Khatun played quite important role during negotions between Sultan Mehmet and Uzun Hasan during the serious competition process on Trabzon. When Emperor of Trabzon David Komninos asked Uzun Hasan for help to counter Sultan Mehmet, Uzun Hasan agreed and an alliance was formed between them against great Sultan of Ottomans. When there was potential threat of attack by Sultan Mehmed, Uzun Hasan sent diplomatic delegation which were lead by Sara Khatun and Kurd Hasan for any possible negotiations.

Uzun Hasan's mother, Sara Khatun, is a very fair, kind woman and quite professional in the field of diplomacy (Gaffari, 1965: 253). Her historical portrait tells us that being just and fair she was compassionate about her sons and her people, as well as she was a woman of political intelligence and strong will (Sumer, 1992: 632).

Sara Khatun played an important role in ensuring and maintaining the stability of the state and the Sultanate, especially after the death of Ak Koyunlu Ali Bey. Her services regarding domestic and foreign policy are crucial. She served in diplomatic missions for various reasons, as well as held important negotiations with Mamluklu, Kara Koyunlu and Ottoman rulers and many agreements were signed due to her superior ability in diplomacy. For example, in order to help her son- Jahangir to obviate his difficult political situation, Sara Khatun visited Mamluk's ruler Zahir Seyfettin Chakmak to initiate negotiations. After the capture of Ak Koyunlu territory - Mardin by Kara Koyunlu troops under the direction Rüstemi Tarhan and his companions, Jahangir was forced to retreat to the Amit and Mamluk 
border. However, no asylum was granted by Mamluk's side. In this tough situation Jahangir, sent his mother Sara Khatun to the Mamluk's ruler Chakmak for negotiations in order to regain the support of the Mamluks (Erdem, Stakeholder, 2007: 78). Sara Khatun, who was on her way to Egypt, was stopped by the Regent of Aleppo and taken to Bire and her condition was notified to the Mamluk's Sultan. Thereupon, the Mamluk's Sultan ordered to send Sara Khatun first to Haleb and then to Damascus. When Sara Khatun arrived in Cairo, she was well received and welcomed by the Mamluk's Sultan (Birdi, 1930: 99, Woods, 1993: 140). After her meeting with Mamluk's Sultan, Syrian Regent began to support Ak Koyunlu.

On the other hand, in the middle of 15th century, a fierce competition began between the Ottoman Sultan Mehmet and the Ak Koyunlu ruler Uzun Hasan to dominate Anatolia, and one of the main quarrel issues in this rivalry is the Greek empire of Trabzon.

Indeed, Uzun Hasan was the strongest and the most dangerous opponent of the Conqueror of Istanbul in Asian lands. This proud ruler, having power over the territories of the eastern regions of Anatolia, the west of Iran and Azerbaijan, consequently forming large and strong state, considered himself the sole successor of Timurlenk. Having power, resources, abilities and higher desires Uzun Hasan had a goal to establish an empire that would encompass the entire Middle East. Thus, it was very clear that Uzun Hasan was pursuing great goals. Being aware of Uzun Hasan's political interests, Abu Said, one of Timur's descendants, who had plan to conquer lands in Cenral Asia and Middle East, promised him Anatolia in return for his help and support. It was somehow political trick against Uzun Hasan, because Abu Said wanted to dominate over the same territory as Uzun Hasan did, and couldn't bear second ruler in the same territory.

One of the most important activities of Sarah Khatun in the political history of the Ak Koyunlu, especially during the establishment process and during the period of internal commotion, were her several attempts in negotiation process with Abu Said to prevent predicted war with him. This historical meeting with Abu Said helped to pause temporarily the intensivness of his actions towards the territories of Ak Koyunlu. However it didn't help to stop his actions as a whole. Abu Said who considered Ak Koyunlu and especially, the power of Uzun Hasan as a big threat, didn't keep his promise regarding peace and attacked Kizilagach land near Mahmut abad province, and settled his army on the Caspian coast with a large army. Soon after this attack, Uzun Hasan eliminated Abu Sait and annexed his country to his own territory.

After several succesful political actions, Uzun Hasan performed himself as the most powerful potential protector of Trabzon Emperor against Ottomans and this led to build good relations between these two states under common interests. Uzun Hasan, who had big desire to expand his lands, welcomed the envoys of Yoannes with great pleasure. Undoubtedly, Uzun Hasan gave great importance to expanding his influence to the Black Sea coast and thus securing the northern side. On the other hand, the young and dynamic Sultan of the Ottomans, after settling in Istanbul and managing all important issues in Rumeli, has intentions and political plans regarding Anatolia. Each of these two powerful rulers want to establish political 
stability over this region under his authority. It is obvious for both sides that in near future their interests would confront because of Anatolia and therefore, each of them tried to gain enough power and became stronger in expected inevitable confrontation.

Sara Khatun played a conciliatory role in the political history of the Ottoman period with her contributions to international foreign policy. Before the Otlukbeli War, two Oghuz tribes Kayı and Bayandirli established their own states. Bayandirli, strengthened their dominance in Azerbaijan, eastern Anatolia, Southeastern Anatolia, and Iraq territories, and became as a strong empire. The Kayi tribes conquered all the geography from Central Anatolia, including the Balkans, and rose as a great state in the west. Sultan Mehmet by conquering the center of Eastern Rome made culminative impact on the whole histery. Consequently, domination of these two Oguz states start to be threat to the power of each other. This situation was noticed by Sara Khatun, who was originally an Oghuz, and she helped to these two rulers to approach agreement. At this point, we witnessed her as a" Peace-maker", conciliator. Sultan Mehmet was pleased by her attitude and diplomatic capabilities and as a respect to Sara Khatun, Sultan Mehmet were calling her as "mother" and he sent her back with great gifts. (Host, 1998: 20)

Sara Khatun apologized on behalf of Uzun Hasan and asked Sultan Mehmet's pardon for what her son had done. With the help of Sara Khatun and Mahmut Pasha, an agreement was signed between the Ottomans and Ak koyunlu. According to this agreement, the Ak Koyunlu would not attack the Ottoman lands and territories under its patronage and would not provide assistance to the Greek Empire of Trabzon. However, shortly after this agreement, Fatih Sultan Mehmet decided to march on Trabzon (Tansel, 1999: 265). On the other hand, the Greek Empire of Trabzon established a new kinship with Ak Koyunlu and formed an alliance in order to have the support of the Uzun Hasan against the Ottoman's threat. After the news that Fatih Sultan Mehmet was going to attack Trabzon Uzun Hasan, his mother Sara Khatun and Mevlana Ahmadi Yekerji and other scholars discussed and came to conclusion that "Fatih Mehmet is the Sultan of the Muslims and fight with him is condemned in terms of Sharia and is not appropriate. Peace with him is for the good of Islam and benefits people's well-being and maintains peace. "Meanwhile, Fatih Sultan Mehmet sent an envoy and notified Uzun Hasan that if he wanted to maintain the peace he should send his mother -Sarah Khatun to Ottoman palace and in this case Fatih Sultan Mehmet would gave back Trabzon (Tihrani, 2001: 265). Considering weak situation of the state Uzun Hasan decided to send his mother Sara Khatun to the Ottoman palace as an envoy and to prevent Fatih Sultan Mehmet's trip to Trabzon. However, despite of all these attempts Uzun Hasan didn't prevent the Ottoman forces from taking Trabzon (Turan, 1965: 67). Sultan Mehmet did not keep his promise and took Sara Khatun with him and marched on Trabzon and took over this place (Baikal, 1964: 71). As per his notes from Ahsenut Tevarih, Fatih Sultan Mehmet indicated that he would release Sarah khatun - Uzun Hasan's mother after he took over that country." (Rumlu, 2006: 86). In fact, Sara Khatun came to Fatih Sultan Mehmet's headquarter. However, she didn't havechance to initiate negotiations with Sultan Mehmet and he was marching on to conquer Trabzon. From his actions and from the letter he wrote to Uzun Hasan it appears that Fatih Sultan Mehmet's plan to take Sara Khatun, who he calls "mother", with himself while 
marching to Trabzon was intended to prevent any hostile acts from Ak Koyunlu side and take over Trabzon without great efforts (Tursun, 1977, 2001). Sultan Mehmet sent a letter to Uzun Hasan indicating that he would relieve Sarah Khatun and envoys after he would take over Trabzon (Tansel, 266). However, it is a fact that after diplomatic negotiations of Sarah Khatun, Sultan Mehmet made some concessions in favor of Akkoyunlu, but did not any concessions regarding territory of Trabzon conquered by him as it was his real purpose to have authority over these lands. (Baysal, 1964: 71) Sultan Mehmet gave some portion of the Treasury of Trabzon to Uzun Hasan as he has heir rights due to his kinship relations (Aşıkpaşazade, 1954: 136).

\section{RECONSTRUCTION ACTIVITIES OF SARA KHATUN}

In addition to Sara Khatun's political and diplomatic duties in the foreign policy of the Ak Koyunlu empire, she also contributed to the Turkic-Islamic civilization through her reconstruction activities. She also managed to be active in the state administration by building Külliye, mosques and lodges and some imarets. She worked hard for the development of the region during her rule and a mosque in this region is one of the rare examples of art that has survived to the present day (Sumerian, 210). The mosque was built in 1465, was later expanded and turned into a complex. Due to the damage done to the mosque section of the complex, it was repaired in 1585 and opened doors for public worship. After the repairs made in 1843, the mosque gained its current presence (Ünal, 1989: 209). The mosque is in the square shape and its central part is covered with a dome resting on four thick columns and its sides were covered with vaults. Its pulpit is one of the finest examples of stonework. Its minaret was made of two colored stones. Another example of art commissioned by Sarah Khatun is a lodge where is written "Sara Khatun valide-i Uzun Hasan" which in englisg means "Sara Khatun - Uzun Hasan's mother" (Sheriff, 1932: 71).

\section{RESULT}

As a result, Sara Khatun, a distinguished diplomat lady, plays an important role in the process of political history in general and in the internal politics of the Ak Koyunlu empire (1468 1503). Like the first diplomat woman in the whole East, Sara Khatun, the mother of the Ak Koyunlu ruler Uzun Hasan, is among the most famous figures in European countries for her political activities. As a stateswoman, she defended the interests of the ruling class and she fought against feudal disintegration and civil wars for the purpose of making central power stronger. Sara Khatun, a very smart and cautious Muslim woman, was closely helping her son in all areas of government administration. Sara Khatun's role was more important in the diplomatic relations of the Ak koyunlu state with foreign countries. Uzun Hasan got her opinion on all foreign policy issues and delegate her to the most responsible talks. She was not involved to the talks just with the diplomats of the foreign countries, but also with the Teymuri ruler Abu Said, as well as the II Ottoman emperor. He held diplomatic meetings with heads of state such as Mehmet and successfully defended the foreign policy interests of the Ak Koyunlu state. Sara Khatun, who had a special status in the whole Middle East, was well received in the residence of Ottoman Sultan. According to the information given by the 
sources, Sara Khatun and Mehmet II addressed one another as "mother" and "son". Sara Khatun signed peace agreement with Sultan Mehmet II using her diplomatic mastery during these meetings. As a result of Sara Khatun's success as a diplomat, the peace treaty of 1561, which she signed with Sultan Mehmet II, is of great importance. Mentioned peace treaty is one of the first agreements that Sara Khatun has made with foreign rulers. Uzun Hasan, refer the solution of the most difficult issues in the country's foreign policy particularly to Sara Khatun. Again, when there was a treat to Azerbaijan territory by Teymuri ruler Abu Said, Sarah Khatun was sent for negotiations and peace talks.

One of the most important activities of Sarah Khatun in the political history of Ak Koyunlu was diplomatic negotiations with Teymuri leader Abu Said which made him agree on peace talks. However, afterwards he did not keep his promise regarding peace, as the power of Ak Koyunlu in the region was a big threat to his authority over mentioned territories. Abu Said attacked with a large army to Alder land near Mahmut abad province, which was settled on the Caspian coast. However, Uzun Hasan soon defeated Abu Said and added his territories to Ak Koyunlu.

In the person of Sara Khatun, who belongs to the Ak Koyunlu dynasty, we witnessed that Turkic women served as ambassadors in domestic and foreign politics, they built mosques, madrasahs, lodges and other important construction buildings, as well as they made presence of woman vital in many areas, including political and military spheres, as well as diplomacy and state administration. They often tried to produce solutions through smart and clever political strategies. One of important facts about turkic muslim diplomat women is that they were appreciated and respected by non-muslim population due to these women's tolerant attitude and peaceful policies, which are positive and do not make any difference between peoples, they have been given love and respect by non-Muslims. It is very crucial moment that equal rights and gender equality that moderrn society tries to advocate nowadays, actually were in practising level in the empires like Ak Koyunlu and Kara Koyunlu. 


\section{BIBLIOGRAPHY}

1. Journal of research, (1990). XV / 26, Ankara.

2. $\quad$, Stakeholder, (2007).Kazım Ak-Koyunlu State History PoliticsOrganization-Culture, United Bookstore, Ankara.

3. Erdush, E.(2003). Muhammad Husain, Uzun Hasan Akkoyunlu and Politiketha Sharki-Garbi: Akkat-1 Iran and Osmani der Dovre-1 Uzun Hasan Akkoyunlu, Intişaratı Bersat, Tehran.

4. Gaffari, H. (1965). Tarihi Cihan-Dec, nşr. Hassan Neraki, Tehran.

5. Hasan-I Rumlu, (2006). Ahsenü't-Tevarih, çev. Mürsel Öztürk, TTK, Ankara, 2006.

6. Ibn Iyas, (1982). Bedayi Ü'z-Zuhur fi Vekayii'd-Duhur, Muhammad Mustafa, c.2, Cairo.

7. Keleş, Hamza, (2006). "Akkoyunlu Cultural Heritage In Anatolia "Historical Works", Haci Bektaş Veli Magazine, P.38, Ankara.

8. Mamhudlu, Y. M. (1993)."Sara Hatun", Azerbaijan Diplomacy, Baku.

9. Mahmut, I. (1993). History Of Azerbaijan, Baku.

10. Sumer, F. (1992). Black Sheep from The Beginning to Jihanshah, c.I, TTK, Ankara.

11. , "(1989). Akkoyunlu", DIA, C.2, Istanbul.

12. Tihrani, Abu Bakr-i, (2001). Kitab-1 Diyarbekriya, traslater: Mursel Ozturk, Ministry Of Culture Publications, Ankara.

13. Journal of Turkish Studies (1977). Tursun Bek, The History Tarih-1 Abu'l Feth, Mertol Istanbul.

14. Uzuncarshil1, I. H. (1932). Organizations and political lives of the Kara koyunlu and Ak koyunlu States of the Anatolian principals and the state organization in their time, intellectual movements and economic life, Ankara.

15.

.I. H. (1988). Anatolian principals and Ak Koyunlu and Karakoyunlu States, TTK, Ankara, 1988.

16. Unal, M. A. (1989). XVI. Sanjak of Harput in the century (1518-1566), TTK, Ankara. 